Special Issue: Disruption of homeostasis-induced signaling and crosstalk in the carcinogenesis paradigm "Epistemology of the origin of cancer"

\title{
Prelude and premise to the special issue: disruption of homeostasis-induced signaling and crosstalk in the carcinogenesis paradigm "Epistemology of the origin of cancer"
}

\author{
Björn L.D.M. Brücher ${ }^{1,2,3}$ and Ijaz S. Jamall ${ }^{1,2,4}$ \\ ${ }^{1}$ Theodor-Billroth-Akademie ${ }^{\circledR}$, Germany; USA \\ ${ }^{2}$ INCORE, International Consortium of Research Excellence of the Theodor-Billroth-Academy ${ }^{\circledR}$, Germany; USA \\ ${ }^{3}$ Department of Surgery, Carl-Thiem-Klinikum, Cottbus, Germany \\ ${ }^{4}$ Risk-Based Decisions Inc., Sacramento, CA, USA
}

Received 11 December 2018, Accepted 3 March 2019

\begin{abstract}
The vast majority of anticancer strategies are symptomatic but in order to achieve some tangible progress, we need to identify the cause(s) of the majority of cancers. There is a kind of zeitgeist that findings in genetics, namely somatic mutations, are reflexively viewed as being causative for carcinogenesis, although some $80 \%$ of all cancers are presently termed "sporadic" (i.e., with no proven cause). The observation that one inch of cancerous liver tissue can have more than 100000000 mutations and an identical mutation can result in different phenotypes, depending on the environment surrounding that mutation, makes it very unlikely that mutations by themselves are causative of most cancers. 4open debuts its Special Issue series with papers that provide strong evidence that carcinogenesis consists of a 6 -step sequence (1) a pathogenic stimulus followed by (2) chronic inflammation from which develops (3) fibrosis with associated remodeling of the extracellular microenvironment, and from these changes a (4) precancerous niche (PCN), a product of fibrosis with remodeling by persistent inflammation develops which triggers the deployment of (5) a chronic stress escape strategy and when this fails to be resolved it results in (6) the normal cell to cancerous cell transition. This Special Issue contains separate papers discussing undervalued ubiquitous proteins, chronic inflammation, eicosanoids, microbiome and morbid obesity, PCN, cell transition, followed by altered signaling induced by Metformin, $\mathrm{NF}-\kappa \mathrm{B}$ signaling and crosstalk during carcinogenesis, and a brief synopsis. In essence, the available evidence, both in vitro and in vivo, lends credence to the proposition that the majority of cancers occur from a disruption of homeostasis-induced signaling and crosstalk in the carcinogenesis paradigm "Epistemology of the origin of cancer".
\end{abstract}

Keywords: Adenoma, Adhesion, Apoptosis, Autophagy, Cancer, Carcinoma, Carcinogenesis, Chronic inflammation, Colitis, Colorectal cancer, Fibroblast, Fibrosis, Homeostasis, Inflammation, Leukemia, Lymphoma, Mutation, NF- $\kappa \mathrm{B}$, Precancerous niche, Stem cell, Tissue

\section{Introduction}

According to the American Cancer Society (ACS), the 5 -year relative survival rate differs significantly according to cancer type with higher rates $\geq 90 \%$ for prostate cancer, melanoma, skin and female breast cancer compared to lower rates $\leq 18 \%$ in liver, lung, and pancreatic cancer [1]. Despite success in some cancer survival rates, these numbers differ by race, ethnicity, socioeconomics, health policy, geography, and age so the overall survival numbers ignore the large variations within any given group. According to the World Health Organization (WHO), the proportion of people over 60 years of age will increase to about 2 billion

*Corresponding author: b-bruecher@gmx.de by 2050 [2]. Epidemiologically, cancer is an age-related disease which will be a major burden to healthcare worldwide along with neurologic, cardiovascular diseases, and diabetes [3]. While more advanced cancer stages reveal significantly lower survival rates [1] they may just represent clinical empiricism $[4,5]$ and do not explain the origin of cancer. "From a "birds-eye" view, it may appear that we have made little progress in eradicating cancer and that outcomes are largely based on the merits, or lack thereof, of any selected therapy" meaning to reach the proposed vision "Imagine a world without cancer" [6], we need to work much harder to understand the as yet unanswered questions that surround the origins of most cancers.

We have no clear information about the latency until cancer as a disease is first diagnosed. Fournier et al. proposed 
nearly 40 years ago that it would take some 16 years until breast cancer begins [7]. On the other hand, the growth rates especially in early cancers are extraordinarily slow [8]. Depending on when we observe cancer cells and what the latency period is, we describe cancer cells as being low, moderate or highly differentiated and anaplastic [4, 5]. Cell differentiation itself is not the only goal as human myeloid leukemia cells can differentiate into mature granulocytes by various agents such as butyrate, phorbol diesters, retinoic acid hypoxanthine, or dimethyl sulfoxide [9 reviewed in 10$]$. Even the proliferation rate does not provide a clue as one of the most rapid cell proliferations occurs during embryonic growth but humans do not have most cancers in utero. Even our understanding of precancerous lesions is limited. Kohler et al. [11] pointed out that some $50 \%$ of individuals will develop colorectal adenomas during their lifetime [12, 13], while over that same period, an increase of colorectal carcinomas without any genetic predisposition in individuals under 50 years of age was observed [14-16]. Is the contribution of the environment undervalued here? We do not know when and how so-called precancerous lesions continue to develop until eventually forming a cancer cell. Low-grade gastric dysplasia even regresses in up to $50 \%$ of patients while higher grades of gastric dysplasia progress to cancer in up to $81 \%$ [17].

Until now, the main focus in cancer research has been on the somatic mutation theory (SMT) and the cancer stem cell (CSC) theory.

However, it makes a big difference if a normal cell undergoes cell transition until the first cancer cell (carcinogenesis) occurs compared to how cancer cells progress, migrate, and result in metastasis. An underestimated, but extremely significant bias in science is the difference between correct observations versus their interpretation, as the conclusion of proper findings can be wrongly labeled as being causative for a disease as for example, in the case of somatic mutations. The quote and metaphor "an apple found in a car is not synonymous of proof that apples grow in cars" [18] by using an image (Fig. 1) [18, 19] illustrates why "genetic studies have not led to a breakthrough in either the diagnosis or the treatment of cancers" [20].

Findings in biotechnology and genetics have, without question, stimulated our knowledge in biology. The popularity of the SMT increased since its grandfathers proposed it more than 100 years ago [21, 22].

The coincidence with the increase of the global biotech market may not just be accidental. The biotech market in the United States of America (USA), Canada, United Kingdom (UK), Germany, Japan, China, Brazil, and South Africa was estimated to be about $\$ 370$ billion in 2016 and is expected to reach $\$ 727$ billion by 2025 with a per annum growth rate of $7.4 \%$ [23]. This does not include the Indian biotech market which alone is expected to be $\$ 100$ billion by 2025 [24] or the one in Russia which is expected to double to about $\$ 39$ billion by 2021 [25]. Australia's biotech market was about $\$ 7$ billion in 2017 [26] and the United Arabian Emirates (UAE) market is projected to increase to $\$ 5.7$ billion by 2020 [27]. Thus, by extrapolation the

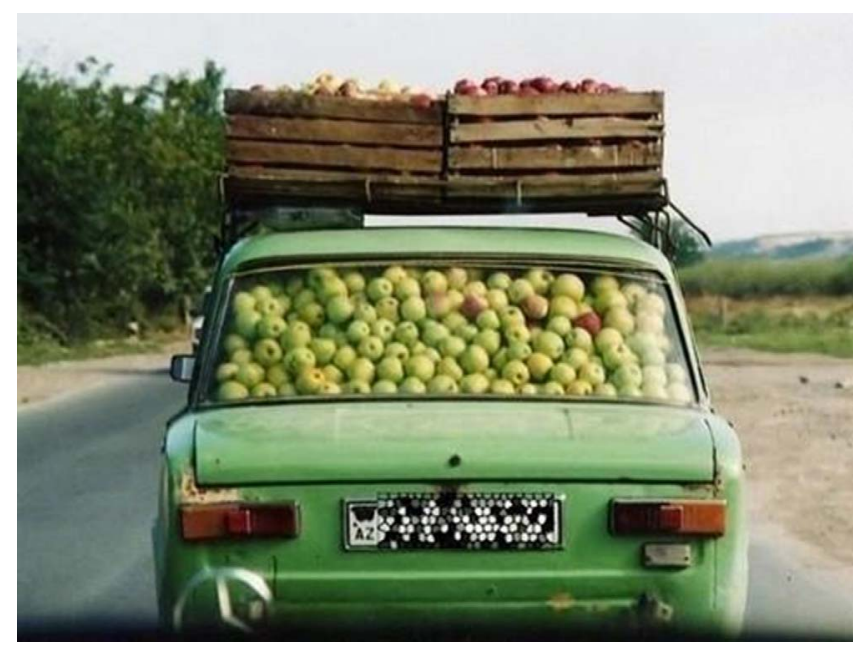

Figure 1. An apple found in a car is not synonymous of proof that apples grow in cars $[18,19]$.

global biotech market could be somewhere between $\$ 880$ billion and $\$ 1$ trillion worldwide by 2025 .

\section{Somatic mutation theory (SMT)}

Significant concerns arose in the 1960s as transplanted nuclei containing the genetic information from frog renal cancer cells into enucleated eggs resulted in various normal tissue without cancer [28] and that this was not due to primary "irreversible changes that prevent them from responding to the host environment' [29]. The weakness in the SMT was pointed out some 40 years ago and again more recently [30,31]. Psychologists may would refer it as a kind of 'Psychology of the crowd-effect' according to Gustave Le Bon [32].

For example, one inch of cancer tissue from the liver can have more than 100 million mutations and an identical mutation can result in different phenotypes [33]. This makes it very unlikely that somatic mutations by themselves are causative of most cancers [34]. A minority of cancers has been proven to be caused by mutations but these involve germline mutations, not somatic mutations. Mutations are found in cancerous tissues and in normal tissues and "many (perhaps most) mutations observed in cancer cells occurred prior to somatic evolution and may not contribute to the cell's malignant phenotype" [35]. There is increasing evidence that the occurrence of "oncogenic" mutations is insufficient to explain cancer incidence [36]. It is evident that the process of cancer development, i.e., carcinogenesis, is not just derived from "simply clonally evolved epithelial cells that have accumulated a critical number of mutations but rather act as dysfunctional tissues where the mesenchymal component plays a critical role in tumour pathogenesis" [37 reviewed in 38]. An estimated $3.9 \%$ of deleterious germline mutations were found by sequencing 32 genes in an investigation of normal and cancer tissue in 854 patients with sporadic pancreatic 
ductal adenocarcinoma [39]. Furthermore, cancers do not need mutations to develop [40].

The observed somatic mutations in cancerous tissues appear to be later events and epiphenomena after the multistep sequence known as carcinogenesis has progressed beyond the precancerous niche (PCN) stage [31, 41, 42]. We now know that an identical mutation can result in different phenotypes [33] and there are even spontaneous in vivo reversion of mutations in non-cancer diseases [43, 44], revertant mosaicism of germline telomerase RNA component (TERC) mutations in the precancerous dyskeratosis congenita [45] or of an angiogenic phenotype to a nonangiogenic and dormant state in cancer [46]. The microenvironment itself can induce re-expression of E-cadherin and consequently result in mesenchymal to epithelial transition in breast cancer $[47,48]$.

The association of somatic mutations of tet methylcytosine dioxygenase 2 (TET2) in both humans and mice and the increase of hematopoietic stem cells with a net developmental bias towards the myeloid lineage was reported a decade ago [49]. However, the proof is still missing that such a mutation is mandatory for the creation of a pre-leukemic state and/or that a mutation is created by bacterial infections and events promoting the disruption of intestinal barrier function [50]. It was recently demonstrated that not just extrinsic non-cell-autonomous factors were required but that primary microbial-dependent inflammation was necessary for the creation of pre-leukemic myeloproliferation, which could be reversed by antibiotic treatment [51]. This suggests that no mutation is needed to induce even the pre-leukemic state.

Intratumor genetic heterogeneity is hard to distinguish from artifacts. Whole exome sequencing was shown to be unreliable with a false positive somatic mutation rate of $69 \%$ and $34 \%-80 \%$ of somatic variants are just noise [52]. The SMT is increasingly not seen any more to be the reason causing the majority of cancers [53]. The following should be noted: during development, DNA damage is associated with DNA replication resulting in inflammation [54].

Most recently, the breast cancer type $1 / 2$ susceptibility protein (BRCA1/2) mutation prevalence in 5122 unselected Swedish breast cancer patients was shown to be $<2 \%$ [55] and the prevalence of BRCA $1 / 2$ and partner and localizer of BRCA2 (PALB2) germline mutations in 2769 unselected breast cancer patients the Chinese population were $2.7 \%$ (BRCA1), 2.7\% (BRCA2) and $0.9 \%$ (PALB2) [56]. The scientific community should be asking how it can be justified that BRCA genetic testing is already demanded by some biotechnology companies?

It was reported that in a healthy 59-year old man 129582 spontaneous, genome-wide somatic mutations were observed in 140 single cell-derived hematopoietic stem and progenitor colonies with an estimation of the numbers of hematopoietic stem cells that are actively making white blood cells at any one time to be in the range of 50000 200000 [57]. Now, why is this healthy man not ill with dozens of diseases?

It was even pointed out that radiation cannot serve as the example to prove the SMT [31]. This is strongly supported by most recently findings, that the linear no-threshold hypothesis (LNT) from A-bombs elongated lifespan and reduced cancer mortality relative to nonirradiated individuals [58].

Even though we have known for decades that another cancer dogma "the cancer phenotype is permanent irreversible" is wrong and that established cancers can undergo spontaneous reversions, we still do not understand why and how. However, if genetic changes were causal, why might we observe cancer regressions? Not another mutation? We stretch the bounds of credibility to fit the observed facts to an incorrect theory! [59-65].

\section{Warburg theory}

Another cancer dogma that also failed includes the assumption that cancer is caused by the Warburg effect, a term coined in 1972 [66] when Warburg and Cori observed that lactic acid is produced by cancer cells due to activation of anaerobic glycolysis [67-72]. Thus, it was assumed that this would be "the" cause of cancer but it was later pointed out that "his conclusions are often misinterpreted" [reviewed in 73]. Even the Warburg effect can be oxidized [74] and if anaerobic glycolysis were to be the major source for carcinogenesis and not just an associated epiphenomenon observed in cancer, why does increased physical activity which goes in line with increased anaerobic glycolysis not associated with increased cancer incidence? Why is the opposite effect observed? [75, 76]. Moreover, glycolysis is "known to be common among developing or regenerating tissues, whether normal or neoplastic, and the tricarboxylic acid cycle to be basically intact in neoplastic tissues" [77].

\section{Stem cell theory}

Another cancer dogma that has gained popularity is the CSC theory though it originated some 150 years ago: Ernst Haeckel (1834-1919), a Professor of Zoology in Jena, Germany, "referred in his published lectures .... 1868 to unicellular organisms or protozoa, which he believed to be the phylogenetic ancestors of multicellular organisms, as Stammzellen (stem cells)" and in 1877 "applied the notion of stem cells to ontogeny against this background and used the name Stammzelle or Cytula to describe the fertilized egg cell as the cell of origin of all other cells of an animal or human organism" [78, 79 reviewed in 80]. Theodor Boveri (1862-1915) "described as Stammzellen those cells that derived from the fertilized egg cell and led to the primordial germ cell (German: Urgeschlechtszelle), and from which the various primordial somatic cells (German: Ursomazellen) branched off' [81 reviewed in 80]. According to Julius Cohnheim (1839-1894), "tumours arose from residual, displaced embryonic cells or rudiments" [82 reviewed in 80$]$.

The transplantation of embryonal carcinoma cells into mice supported the stem cell theory of cancer [83] and injection of those cancer cells into early mice embryo blastocysts resulted in the reversibility of malignancy [84, 85]. 
Later an acute myeloid leukemia (AML)-initiating cell by transplantation into mice was observed [86] and CSCs were identified in leukemia [87].

Without question the CSC theory opened a new chapter in cancer research but serious concerns have been raised questioning its value to explain the vast majority of cancers especially that it "is likely that we are still evaluating the main population of tumour cells, which are not cancer stem cells, and are thus probably wasting time and losing essential treatment information" and that it is "unlikely that gene expression profiles obtained using the currently available methods reflect those of the tumour stem cell population, which forms only 0.1-2\% of the whole tissue sample" [88]. Later, it was also proposed, that "misplaced epithelial stem cell which lands to the wrong location of stromal connective tissue by accident' would result in carcinogenesis [40].

Various pathogenic stimulus, such as infections by bacteria, viruses or fungi trigger chronic inflammation with increased cytokines such as interleukins, tumor necrosis factor (TNF), and platelet-derived growth factor; central roles in this regard have exemplary cytokines such as the interleukin 6 (IL-6) triggering chronic inflammation [89]. Transforming growth factor beta 1 (TGF- $\beta 1$ ) signaling by fibroblasts is a key regulator in consecutive secondary remodeling of the extracellular matrix (ECM) and associated with worse prognosis in cancer patients [90].

This is triggered by chronic inflammation. One newly reported aspect is that chronic inflammation generates oxidation of circulating high-density lipoprotein (oxHDL) from native high-density lipoprotein (HDL) with a positive feedback mechanism through the oxHDLreceptor, lectinlike oxidized low-density lipoprotein receptor-1 (LOX-1), increasing $\mathrm{NADPH}$ oxidase 2 (NOX-2), TNF- $\alpha$ and LOX-1 via NOX-2/reactive oxygen species (ROS)/nuclear factor kappa-light-chain-enhancer of activated $\mathrm{B}$ cells $(\mathrm{NF}-\kappa \mathrm{B})$ axis inducing as well inducing disruption of homeostasis in systematic inflammation [91].

Another key regulator here is Lysyl oxidase (LOX). LOX mediates TGF- $\beta 1$-induced fibrotic phenotypes in human skin-like tissues [92]. In terms of LOX isoforms, specifically, the enzymes lysyl hydroxylase 2 (LH2) or lysyl oxidase (LOX) and LOX-like 2 (LOXL2) are significantly upregulated and associated with poor patient prognosis in primary human oral squamous cell carcinoma (OSCC) [93]. The $\mathrm{N}$-terminal neo-epitope site of LOXL2 is significantly elevated in serum from patients with breast, colorectal, lung, ovarian, pancreatic and prostate cancer, melanoma, IPF compared to healthy controls [94]. Applying the dual LOXL2/LOXL3 inhibitor, PXS-5153A, reduces crosslinks and ameliorates fibrosis [95].

"Hypoxia-inducible factor 1-alpha (HIF-1 $\alpha), T G F-\beta$ and LOX expression levels were significantly higher in human gastric cancer tissues as compared with that in adjacent tissues" and applying dextran sulfate reduced the number of invaded and migrated cells, cell proliferation and apoptosis in a dose-dependent manner especially under hypoxic conditions [96]. The complexity of various signaling and crosstalk pathways provided in the manuscripts of this
Special Issue is noteworthy. For example, recently a tumor growth control by eosinophils was demonstrated by applying the dipeptidyl peptidase DPP4 (CD26) inhibitor, sitagliptin, which resulted in an increase of $\mathrm{C}-\mathrm{C}$ motif chemokine 11 (CCL11), higher rate of migration of eosinophils into solid tumor through IL-33 mediation, a pro-inflammatory mechanism [97].

The disruption of homeostasis in signaling and crosstalk as described in the "Epistemology of the origin of cancer" has been well-received in the scientific literature. The Nobel laureate, Professor Harald zur Hausen, pointed out that therapy against chronic inflammation with nonsteroidal anti-inflammatory drugs (NSAID) protects against some of the same cancers [98].

\section{Summary}

This is the time to stimulate research to a more pragmatic approach to cancer [99]. Findings in biology provide strong evidence for a more complex origin of carcinogenesis with a multistep sequence named "Epistemology of the origin of cancer: a new paradigm" [41], consisting of: (1) a pathogenic stimulus followed by (2) chronic inflammation from which develops (3) fibrosis with associated remodeling of the cellular microenvironment; and from these changes a (4) PCN, a product of fibrosis with remodeling by persistent inflammation, with widespread disruption of homeostasis across multiple signaling pathways, develops which triggers the deployment of (5) a chronic stress escape strategy and when this fails to resolve (6) results in a normal cell to a cancerous cell transition (NCCCT).

During a lengthy scientific process including molecular research (references not listed here), this paradigm of six steps leading to cancer [41] was developed in parallel with the understanding of biochemical and physiology signaling pathways [42] so that a new anticancer strategy could be clearly enunciated $[6]$ and which explains why there is an undervalued syllogism "hysteron - proteron" which reverses both the temporal and logical order occurring during carcinogenesis in that the first (somatic mutation) occurs only after the second (onset of cancer) [31] as well as molecular explanations in genomics, microRNA, epigenetics, and proteomics [100].

The cancer paradigm "Epistemology of the origin of cancer" supports not just the fact that inflammation and fibrosis are necessary conditions to the development of cancer, they provide many targets for interdicting the process of carcinogenesis. Furthermore, inflammation and fibrosis are one of the universal bases of any cellular biochemical physiology and pathology.

Our goal is to cohesively weave together a detailed set of explanations of the disruption of homeostasis through complex interrelationships of various signaling and crosstalk pathways through available in vitro and in vivo data to elucidate the 6-step sequence of carcinogenesis which explains how the majority of cancers occur from the following Special Issue "Disruption of signaling 
homeostasis-induced signaling and crosstalk in the carcinogenesis paradigm Epistemology of the origin of cancer" containing:

1. Prelude and Premise to the Special Issue,

2. Undervalued ubiquitous proteins,

3. Chronic inflammation evoked by pathogenic stimulus during carcinogenesis,

4. Eicosanoids during carcinogenesis,

5. Microbiome and morbid obesity increase pathogenic stimulus diversity,

6. PCN, a product of fibrosis with remodeling by incessant chronic inflammation,

7. Transition from normal to cancerous cell by $\mathrm{PCN}$ induced chronic cell-matrix stress,

8. Metformin alters signaling homeostasis,

9. NF- $\kappa \mathrm{B}$ during carcinogenesis, and

10. Synopsis.

\section{Nomenclature of abbreviations}

\begin{tabular}{|c|c|}
\hline $\mathrm{ACS}$ & American Cancer Society \\
\hline AML & Acute myeloid leukemia \\
\hline $\mathrm{BRCA} 1 / 2$ & $\begin{array}{l}\text { Breast cancer type } 1 / 2 \text { susceptibility } \\
\text { protein }\end{array}$ \\
\hline CCL11 & $\mathrm{C}-\mathrm{C}$ motif chemokine 11 \\
\hline CD26 & Dipeptidyl peptidase DPP4 \\
\hline CSC theory & Cancer stem cell theory \\
\hline HDL & High-density lipoprotein \\
\hline $\mathrm{HIF}-1 \alpha$ & Hypoxia-inducible factor 1-alpha \\
\hline IL-6 & Interleukin 6 \\
\hline LNT & Linear no-threshold hypothesis \\
\hline $\mathrm{LOX}$ & Lysyl oxidase \\
\hline LOX-1 & Lectin-like oxidized low-density \\
\hline & lipoprotein receptor-1 \\
\hline LOXL2 & LOX-like 2 \\
\hline NCCCT & Normal cell to cancerous cell transition \\
\hline $\mathrm{NF}-\kappa \mathrm{B}$ & $\begin{array}{l}\text { Nuclear factor kappa-light-chain- } \\
\text { enhancer of activated B cells }\end{array}$ \\
\hline NOX-2 & NADPH oxidase 2 \\
\hline NSAID & Nonsteroidal anti-inflammatory drug \\
\hline OSCC & Oral squamous cell carcinoma \\
\hline oxHDL & $\begin{array}{l}\text { Oxidation of circulating high-density } \\
\text { lipoprotein }\end{array}$ \\
\hline PALB2 & Partner and localizer of BRCA2 \\
\hline $\mathrm{PCN}$ & Precancerous niche \\
\hline $\mathrm{ROS}$ & Reactive oxygen species \\
\hline SMT & Somatic mutation theory \\
\hline TERC & Telomerase RNA component \\
\hline TET2 & Tet methylcytosine dioxygenase 2 \\
\hline TGF- $\beta 1$ & Transforming growth factor beta 1 \\
\hline TNF & Tumor necrosis factor \\
\hline UAE & United Arabian Emirates \\
\hline UK & United Kingdom \\
\hline USA & United States of America \\
\hline USD & US Dollar \\
\hline WHO & World Health Organization \\
\hline
\end{tabular}

\section{Acknowledgments}

The manuscripts of this Special Issue were supported by the Theodor-Billroth-Academy ${ }^{\circledR}\left(\mathrm{TBA}^{\circledR}\right)$ and INCORE (International Consortium of Research Excellence) of the $\left(\mathrm{TBA}^{\circledR}\right)$. We express our gratitude to the discussions on the web group of the Theodor-Billroth-Academy ${ }^{\circledR}\left(\mathrm{TBA}^{\circledR}\right)$ on LinkedIn, the exchange with scientists at Researchgate.com, as well as personal exchanges with distinguished colleagues who stimulated our thinking all named individually earlier in publications - we thank each one.

\section{Conflict of Interest}

The author reports the following conflict of interest: Björn LDM Brücher is Editor-in-Chief in Life SciencesMedicine of 4open by EDP Sciences. Ijaz S. Jamall is Senior Editorial Board member in Life Sciences-Medicine of 4 open by EDP Sciences. The authors, of their own initiative, suggested to the Managing Editorial to perform a transparent peer-review of their submittals. Neither author took any action to influence the standard submission and peer-review process, and report no conflict of interest. The authors alone are responsible for the content and writing of the manuscript of this Special Issue. This manuscript contains original material that has not previously been published. All authors contributed on its contents and approved the different manuscript.

\section{References}

1. Siegel RL, Miller KD, Jemal A (2018), Cancer statistics, 2018. CA Cancer J Clin 68, 1, 7-30. https://doi.org/ 10.3322 /caac. 21442.

2. Population Division, DESA, United Nations (2001), World population ageing. Available from: http://www.un.org/ esa/population/publications/worldageing19502050/.

3. Brücher BLDM (2018), Science belongs to no one - And to everyone. 4open 1, E1, 1-11. https://doi.org/10.1051/fopen/ 2017501.

4. Foulds L (1969), Neoplastic development, Vol. 10, Academic Press, New York, NY. ISBN-10: 0122628012.

5. Foulds L (1975), Neoplastic development, Vol. 10, Academic Press, New York, NY. ISBN 10: 0122628020.

6. Brücher BLDM, Lyman G, van Hillegersberg R, Pollock RE, Lordick F, Yang HK, Ushijima T, Yeoh KG, Skricka T, Polkowski W, Wallner G, Verwaal V, Garofalo A, D'Ugo D, Roviello F, Steinau HU, Wallace TJ, Daumer M, Maihle N, Reid TJ III, Ducreux M, Kitagawa Y, Knuth A, Zilberstein B, Steele SR, Jamall IS (2014), Imagine a world without cancer. BMC Cancer 14, 186, 1-8.

7. Fournier DV, et al. (1980), Growth rate if 147 mammary carcinomas. Cancer 45, 2198-2207.

8. Eckardt VF, Willems D, Kanzler G, Remmele W, Bettendorf U, Paulus W (1984), Eighty months persistence of poorly differentiated early gastric cancer. Gastroenterology $87,3,719-724$.

9. Rovera G, Olashaw N, Meo P (1980), Terminal differentiation in human promyelocytic leukaemic cells in the absence of DNA synthesis. Nature 284, 5751, 69-70. https://doi. org/10.1038/284069a0. 
10. Nery R (1986), Cancer: an enigma in biology and society, Croom Helm London \& Sydney, The Charles Press, Publishers, Philadelphia, PA. ISBN 0-7099-1825-9.

11. Kohler LN, Harris RB, Oren E, Roe DJ, Lance P, Jacobs ET (2018), Adherence to nutrition and physical activity cancer prevention guidelines and development of colorectal adenoma. Nutrients 10, 8. pii: E1098. https://doi.org/ 10.3390/nu10081098.

12. Schatzkin A, Freedman LS, Dawsey SM, Lanza E (1994), Interpreting precursor studies: What polyp trials tell us about large-bowel cancer. J Natl Cancer Inst 86, 1053-1057.

13. Bond JH (2000), Polyp guideline: Diagnosis, treatment and surveillance for patients with colorectal polyps, Practice Parameters Committee of the American College of Gastroenterology. Am J Gastroenterol 95, 3053-3063.

14. US Preventive Services Task Force (2008), Screening for colorectal cancer: U.S. Preventive Services Task Force recommendation statement. Ann Intern Med 149, 9, 627-637. PMID: 18838716.

15. American Cancer Society (2014), Cancer facts \& figures 2014, Atlanta, GA, USA. https://www.cancer.org/content/ dam/cancer-org/research/cancer-facts-and-statistics/ annual-cancer-facts-and-figures/2014/cancer-facts-andfigures-2014.pdf.

16. Siegel RL, Fedewa SA, Anderson WF, Miller KD, Ma J, Rosenberg PS, Jemal A (2017), Colorectal cancer incidence patterns in the United States, 1974-2013. J Natl Cancer Inst 109, 8, 1-6. https://doi.org/10.1093/jnci/djw322.

17. Bearzi I, Brancorsini D, Santinelli A, Rezai B, Mannello B, Ranaldi R (1994), Gastric dysplasia: A ten-year follow-up study. Pathol Res Pract 190, 1, 61-68.

18. Brücher BLDM (2014), An apple found in a car is not synonym of prove apples grow in car's. https://www. linkedin.com/pulse/20141004103958-43998698-an-apple-ina-car-is-not-synonym-of-prove-apples-grow-in-car-s /

19. Unknown author Cars in Azerbaijan. http://az.auto.az/ 23BD179.

20. Poletaev A, Pukhalenko A, Kukushkin A, Sviridov $\mathrm{P}$ (2015), Detection of early cancer: Genetics or immunology? Serum autoantibody profiles as markers of malignancy Anticancer Agents Med Chem 15, 10, 1260-1263. https://doi.org/10.2174/1871520615666150716105255.

21. Boveri T (1914), Zur Frage der Entstehung maligner Tumoren, Verlag von Gustav Fischer, Jena, Germany, pp. 29-32.

22. Bauer KH (1928), Mutationstheorie der GeschwulstEntstehung, Julius Springer Verlag, Berlin, Germany.

23. Grand View Research (2017), Biotechnology market analysis by application (health, food \& agriculture, natural resources \& environment, industrial processing bioinformatics), by technology, and segment forecasts, 2014-2025. http://www. grandviewresearch.com/industry-analysis/biotechnologymarket.

24. India aims for $100 \$$ billion biotech industry by 2025 (2017) The Pharmaletter, Jul 11, 2017, https://www.thepharmaletter.com/article/india-aims-for-100-billion-biotech-industryby-2025.

25. Russia's pharmaceutical market will almost double to $\$ 39$ billion by 2021, says GlobalData (2017) epm, connecting pharma, Feb 28, 2017. https://www.epmmagazine.com/ news/russia\%E2\%80\%99s-pharmaceutical-market-willalmost-double-to-39-bill/

26. Biotechnology in Australia (2017), IBIS World. Accessed Oct 10, 2017. https://www.ibisworld.com.au/industry-trends/ market-research-reports/thematic-reports/biotechnology. html.
27. UAE pharmaceutical market set to hit $\$ 5.7$ billion by 2020 (2017) the pharmaletter, Oct 11, 2016. Oct 11, 2016. https:// www.thepharmaletter.com/article/uae-pharmaceuticalmarket-set-to-hit-5-7-billion-by-2020.

28. McKinnell R, Deggins B, Labat D (1969), Transplantation of pluripotential nuclei from triploid frog tumors. Science 165, 394-396.

29. Lust JM, Carlson DL, Kowles R, Rollins-Smith L, Williams JW 3rd, McKinnell RG (1991), Allografts of tumor nuclear transplantation embryos: differentiation competence. Proc Natl Acad Sci USA 88, 15, 6883-6887.

30. Rubin H (1980), Is somatic mutation the major mechanism of malignant transformation? J Natl Cancer Inst 64, 5, 995-1000. https://doi.org/10.1093/jnci/64.5.995.

31. Brücher BLDM, Jamall IS (2016), Somatic mutation theory Why it's wrong for most cancers. Cell Physiol Biochem 38, 5, 1663-1680. https://doi.org/10.1159/000443106.

32. Le Bon G (1895), Psychologie des foules. Ancienne Librairie Germer Baillière et $\mathrm{C}^{\mathrm{ie}}$, Paris, Félix Alcan (Ed.). https:// electrodes.files.wordpress.com/2008/12/psychologie_des_ foules__gustave_lebon_le_bon_gallica_ed_1895.pdf.

33. Vu V, Verster AJ, Schertzberg M, Chuluunbaatar T, Spensley M, Pajkic D, Hart GT, Moffat J, Fraser AG (2015), Natural variation in gene expression modulates the severity of mutant phenotypes. Cell 162, 2, 391-402. https://doi.org/10.1016/j.cell.2015.06.037.

34. Ling S, Hu Z, Yang Z, Yang F, Li Y, Lin P, Chen K, Dong L, Cao L, Tao Y, Hao L, Chen Q, Gong Q, Wu D, Li W, Zhao W, Tian X, Hao C, Hungate EA, Catenacci DV, Hudson RR, Li WH, Lu X, Wu CI (2015), Extremely high genetic diversity in a single tumor points to prevalence of non-Darwinian cell evolution. Proc Natl Acad Sci USA 112, E6496-6505. https://doi.org/10.1073/pnas.1519556112. CORRECTION: Proc Natl Acad Sci U S A 2016, 113(5): E663. DOI: https://doi.org/10.1073/pnas.1600151113.

35. Gatenby RA, Brown J (2017), Mutations, evolution and the central role of a self-defined fitness function in the initiation and progression of cancer. Biochim Biophys Acta 1867, 2, 162-166. https://doi.org/10.1016/j.bbcan.2017.03. 005.

36. Liggett LA, DeGregori J (2017), Changing mutational and adaptive landscapes and the genesis of cancer. Biochim Biophys Acta 1867, 2, 84-94. https://doi.org/10.1016/j. bbcan.2017.01.005.

37. Tang R, Changchien CR, Wu MC, Fan CW, Liu KW, Chen JS, Chien HT, Hsieh LL (2004), Colorectal cancer without high microsatellite instability and chromosomal instability An alternative genetic pathway to human colorectal cancer. Carcinogenesis 25, 5, 841-846. https://doi.org/10.1093/ carcin/bgh074.

38. Cirillo N, Hassona Y, Celentano A, Lim KP, Manchella S, Parkinson EK, Prime SS (2017), Cancer-associated fibroblasts regulate keratinocyte cell-cell adhesion via TGF- $\beta$-dependent pathways in genotype-specific oral cancer. Carcinogenesis 38, 1, 76-85. https://doi.org/10.1093/carcin/bgw113.

39. Shindo K, Yu J, Suenaga M, Fesharakizadeh S, Cho C, Macgregor-Das A, Siddiqui A, Witmer PD, Tamura K, Song TJ, Navarro Almario JA, Brant A, Borges M, Ford M, Barkley T, He J, Weiss MJ, Wolfgang CL, Roberts NJ, Hruban RH, Klein AP, Goggins M (2017), Deleterious germline mutations in patients with apparently sporadic pancreatic adenocarcinoma. J Clin Oncol 35, 30, 3382-3390. https://doi.org/10.1200/JCO.2017.72.3502.

40. Wang RA, Li ZS, Zhang HZ, Zheng PJ, Li QL, Shi JG, Yan QG, Ye J, Wang JB, Guo Y, Huang XF, Yu YH (2013), Invasive cancers are not necessarily from preformed in situ tumours - An alternative way of carcinogenesis from 
misplaced stem cells. J Cell Mol Med 17, 7, 921-926. https://doi.org/10.1111/jcmm.12078.

41. Brücher BLDM, Jamall IS (2014), Epistemology of the origin of cancer: A new paradigm. BMC Cancer 14, 1-15. https://doi.org/10.1186/1471-2407-14-331.

42. Brücher BLDM, Jamall IS (2014), Cell-cell communication in tumor microenvironment, carcinogenesis and anticancer treatment. Cell Physiol Biochem 34, 2, 213-243. https://doi.org/10.1159/000362978.

43. Ariga T, Kondoh T, Yamaguchi K, Yamada M, Sasaki S, Nelson DL, Ikeda H, Kobayashi K, Moriuchi H, Sakiyama Y (2001), Spontaneous in vivo reversion of an inherited mutation in the Wiskott-Aldrich syndrome. J Immunol $166,8,5245-5249$.

44. Xie JW, Zhang ZY, Wu JF, Liu DW, Liu W, Zhao Y, Jiang LP, Tang XM, Wang M, Zhao XD (2015), In vivo reversion of an inherited mutation in a Chinese patient with WiskottAldrich syndrome. Hum Immunol 76, 6, 406-413. https://doi.org/10.1016/j.humimm.2015.04.001.

45. Jongmans MC, Verwiel ET, Heijdra Y, Vulliamy T, Kamping EJ, Hehir-Kwa JY, Bongers EM, Pfundt R, van Emst L, van Leeuwen FN, van Gassen KL, Geurts van Kessel A, Dokal I, Hoogerbrugge N, Ligtenberg MJ, Kuiper RP (2012), Revertant somatic mosaicism by mitotic recombination in dyskeratosis congenital. Am J Hum Genet 90, 3, 426-433. https://doi.org/10.1016/j.ajhg.2012.01.004.

46. Rogers MS, Novak K, Zurakowski D, Cryan LM, Blois A, Lifshits E, Bø TH, Oyan AM, Bender ER, Lampa M, Kang SY, Naxerova K, Kalland KH, Straume O, Akslen LA, Watnick RS, Folkman J, Naumov GN (2014), Spontaneous reversion of the angiogenic phenotype to a nonangiogenic and dormant state in human tumors. Mol Cancer Res 12, 5, 754-764. https://doi.org/10.1158/1541-7786.MCR-13-0532-T

47. Chao YL, Shepard CR, Wells A (2010), Breast carcinoma cells re-express E-cadherin during mesenchymal to epithelial reverting transition. Mol Cancer 9, 179. https://doi.org/ 10.1186/1476-4598-9-179.

48. Chao Y, Wu Q, Acquafondata M, Dhir R, Wells A (2012), Partial mesenchymal to epithelial reverting transition in breast and prostate cancer metastases. Cancer Microenviron 5, 1, 19-28. https://doi.org/10.1007/s12307-011-0085-4.

49. Delhommeau F, Dupont S, Della Valle V, James C, Trannoy S, Massé A, Kosmider O, Le Couedic JP, Robert F, Alberdi A, Lécluse Y, Plo I, Dreyfus FJ, Marzac C, Casadevall N, Lacombe C, Romana SP, Dessen P, Soulier J, Viguié F, Fontenay M, Vainchenker W, Bernard OA (2009), Mutation in TET2 in myeloid cancers. N Engl J Med 360, 22, 2289-2301. https://doi.org/10.1056/NEJMoa0810069.

50. Bowman RL, Busque L, Levine RL (2018), Clonal hematopoiesis and evolution to hematopoietic malignancies. Cell Stem Cell 22, 2, 157-170. https://doi.org/10.1016/j. stem.2018.01.011.

51. Meisel M, Hinterleitner R, Pacis A, Chen L, Earley ZM, Mayassi T, Pierre JF, Ernest JD, Galipeau HJ, Thuille N, Bouziat R, Buscarlet M, Ringus DL, Wang Y, Li Y, Dinh V, Kim SM, McDonald BD, Zurenski MA, Musch MW, Furtado GC, Lira SA, Baier G, Chang EB, Eren AM, Weber CR, Busque L, Godley LA, Verdú EF, Barreiro LB, Jabri B (2018), Microbial signals drive pre-leukaemic myeloproliferation in a Tet2-deficient host. Nature 557, 7706, 580-584. https://doi.org/10.1038/s41586-018-0125-z.

52. Shi W, Ng CKY, Lim RS, Jiang T, Kumar S, Li X, Wali VB, Piscuoglio S, Gerstein MB, Chagpar AB, Weigelt B, Pusztai L, Reis-Filho JS, Hatzis C (2018), Reliability of whole-exome sequencing for assessing intratumor genetic heterogeneity. Cell Rep 25, 6, 1446-1457. https://doi.org/ 10.1016/j.celrep.2018.10.046.
53. Adjiri A (2017), DNA mutations may not be the cause of cancer. Oncol Ther 5, 1, 85-101. https://doi.org/10.1007/ s40487-017-0047-1.

54. McNairn AJ, Chuang CH, Bloom JC, Wallace MD, Schimenti JC (2019), Female-biased embryonic death from inflammation induced by genomic instability. Nature 567, 105-108. https://doi.org/10.1038/s41586-0190936-6.

55. Li J, Wen WX, Eklund M, Kvist A, Eriksson M, Christensen HN, Torstensson A, Bajalica-Lagercrantz S, Dunning AM, Decker B, Allen J, Luccarini C, Pooley K, Simard J, Dorling L, Easton DF, Teo SH, Hall P, Borg A,, Grönberg H, Czene K (2019), Prevalence of BRCA1 and BRCA2 pathogenic variants in a large, unselected breast cancer cohort. Int J Cancer 144, 5, 1195-1204. https://doi. org/10.1002/ijc.31841.

56. Deng M, Chen HH, Zhu X, Luo M, Zhang K, Xu CJ, Hu KM, Cheng P, Zhou JJ, Zheng S, Chen YD (2019), Prevalence and clinical outcomes of germline mutations in BRCA1/2 and PALB2 genes in 2769 unselected breast cancer patients in China. Int J Cancer Feb 5. https://doi. org/10.1002/ijc.32184.

57. Lee-Six H, Øbro NF, Shepherd MS, Grossmann S, Dawson K, Belmonte M, Osborne RJ, Huntly BJP, Martincorena I, Anderson E, O'Neill L, Stratton MR, Laurenti E, Green AR, Kent DG, Campbell PJ (2018), Population dynamics of normal human blood inferred from somatic mutations. Nature 561, 7724, 473-478. https://doi.org/10.1038/ s41586-018-0497-0.

58. Sutou S (2018), Low-dose radiation from A-bombs elongated lifespan and reduced cancer mortality relative to un-irradiated individuals. Genes Environ 40, 26. https://doi. org/10.1186/s41021-018-0114-3.

59. Bennett WH (1899), Some peculiarities in the behavior of certain malignant and innocent growths. Lancet 1, 3-7.

60. Rosenman RH (1946), Spontaneous regression of metastatic sarcoma; report of case. Am J Clin Pathol 16, 281-289.

61. Penner DW (1953), Spontaneous regression of a case of myosarcoma. Cancer 64, 776-779.

62. Sumner WC (1953), Spontaneous regression of melanoma. Cancer 6, 5, 1040-1043.

63. Levison VB (1955), Spontaneous regression of a malignant melanoma. $\mathrm{Br}$ Med J 1, 4911, 458-459. PMCID: PMC2061225.

64. Everton TC, Cole WH (1966), Spontaneous regression of cancer, W.B. Saunders, Philadelphia, PA.

65. Fairlamb DG (1981), Spontaneous regression of metastases of renal cancer: A report of two cases including the first recorded regression following irradiation of a dominant metastasis and review of the world literature. Cancer 47, 8, 2102-2106. PMID: 7226102.

66. Racker E (1972), Bioenergetics and the problem of tumor growth. Am Sci 60, 56-63.

67. Warburg O (1923), Versuche an überlebendem CarcinomGewebe (Methoden). Biochem Zeitschr 142, 317-333.

68. Warburg O, Posener K, Negelein E (1924), Über den Stoffwechsel der Carcinomzelle. Biochem Zeitschr 152, 309-344.

69. Cori CA, Cori GT (1925), The carbohydrate metabolism of tumours I: The free sugar, lactic acid, and glycogen content of malignant tumors. J Biol Chem 64, 11-22.

70. Cori CA, Cori GT (1925), The carbohydrate metabolism of tumours II: The changes in the suga, latic acid, and co-combining power of blood passing through a tumor. J Biol Chem 65, 397-405.

71. Warburg O (1925), Über den Stoffwechsel der Carcinomzelle. Klin Wochenschr 4, 534-536. 
72. Warburg O, Wind F, Negelein E (1927), The metabolism of tumors in the body. J Gen Physiol 8, 6, 519-530.

73. Koppenol WH, Bounds PL, Dang CV (2011), Otto Warburg's contributions to current concepts of cancer metabolism. Nat Rev Cancer 11, 5, 325-337. https://doi. org $/ 10.1038 /$ nrc3038.

74. Cordier-Bussat M, Thibert C, Sujobert P, Genestier L, Fontaine É, Billaud M (2018), Même l'effet Warburg est oxydable: Coopération métabolique et développement tumoral. Med Sci (Paris) 34, 8-9, 701-708. https://doi. org $/ 10.1051 /$ medsci $/ 20183408017$.

75. Tan MM, Ho WK, Yoon SY, Mariapun S, Hasan SN, Lee DS, Hassan T, Lee SY, Phuah SY, Sivanandan K, Ng PP, Rajaram N, Jaganathan M, Jamaris S, Islam T, Rahmat K, Fadzli F, Vijayananthan A, Rajadurai P, See MH, Thong MK, Mohd Taib NA, Yip CH, Teo SH (2018), A casecontrol study of breast cancer risk factors in 7,663 women in Malaysia. PLoS One 13, 9, e0203469. https://doi.org/ 10.1371/journal.pone.0203469.

76. Sormunen J, Talibov M, Sparén P, Martinsen JI, Weiderpass E, Pukkala E (2018), Perceived physical strain at work and incidence of prostate cancer - A case-control study in Sweden and Finland. Asian Pac J Cancer Prev 19, 8, 2331-2335.

77. Nery R (1986), Cancer: An enigma in biology and society, Croom Helm, London, UK. ISBN 0709918259.

78. Haeckel E (1868), Natürliche Schöpfungsgeschichte, Georg Reimer, Berlin, Germany.

79. Haeckel E (1877), Anthropogenie oder Entwickelungsgeschichte des Menschen, 3rd edn., Wilhelm Engelmann, Leipzig, Germany, p. 1877.

80. Maehle AH (2011), Ambiguous cells: The emergence of the stem cell concept in the nineteenth and twentieth centuries. Notes Rec R Soc Lond 65, 4, 359-378. PMCID: PMC3793240.

81. Boveri T (1892), Ueber die Entstehung des Gegensatzes zwischen den Geschlechtszellen und den somatischen Zellen bei Ascaris megalocephala, nebst Bemerkungen zur Entwicklungsgeschichte der Nematoden. Sitzungsbericht Gesellschaft Morphologie und Physiologie, München 8, 114-125.

82. Cohnheim J (1877-1880), Vorlesungen über allgemeine Pathologie, Ein Handbuch für Aerzte und Studierende (2 volumes), August Hirschwald, Berlin, Germany.

83. Kleinsmith LJ, Pierce GB Jr (1964), Multipotentiality of single embryonal carcinoma cells. Cancer Res 24, 1544-1551.

84. Brinster RL (1974), The effect of cells transferred into the mouse blastocyst on subsequent development. J Exp Med 140, 1049-1056.

85. Mintz B, Illmensee K (1975), Normal genetically mosaic mice produced from malignant teratocarcinoma cells. Proc Natl Acad Sci USA 72, 3585-3589.

86. Lapidot T, Sirard C, Vormoor J, Murdoch B, Hoang T, Caceres-Cortes J, Minden M, Paterson B, Caligiuri MA, Dick JE (1994), A cell initiating human acute myeloid leukaemia after transplantation into SCID mice. Nature 367, 6464, 645-648.

87. Bonnet D, Dick JE (1997), Human acute myeloid leukemia is organized as a hierarchy that originates from a primitive hematopoietic cell. Nat Med 3, 7, 730-737.

88. Nuciforo P, Fraggetta F (2004), Cancer stem cell theory: pathologists' considerations and ruminations about wasting time and wrong evaluations. J Clin Pathol 57, 7, 782.
89. Tosato G, Jones KD (1990), Interleukin-1 induces interleukin- 6 production in peripheral blood monocytes. Blood 75, 6, 1305-1310. PMID: 2310829.

90. Chakravarthy A, Khan L, Bensler NP, Bose P, De Carvalho DD (2018), TGF- $\beta$-associated extracellular matrix genes link cancer-associated fibroblasts to immune evasion and immunotherapy failure. Nat Commun 9, 1, 4692-4693. https://doi.org/10.1038/s41467-018-06654-8.

91. Pérez L, Vallejos A, Echeverria C, Varela D, CabelloVerrugio C, Simon F (2019), OxHDL controls LOX-1 expression and plasma membrane localization through a mechanism dependent on NOX/ROS/NF- $\kappa$ B pathway on endothelial cells. Lab Invest 99, 3, 421-437. https://doi.org/ 10.1038/s41374-018-0151-3.

92. Huang M, Liu Z, Baugh L, DeFuria J, Maione A, Smith A, Kashpur O, Black Iii LD, Georgakoudi I, Whitfield ML, Garlick J (2018), Lysyl oxidase enzymes mediate TGF- $\beta 1$ induced fibrotic phenotypes in human skin-like tissues. Lab Invest Dec 19. https://doi.org/10.1038/s41374-018-0159-8.

93. Saito T, Uzawa K, Terajima M, Shiiba M, Amelio AL, Tanzawa H, Yamauchi M (2019), Aberrant collagen crosslinking in human oral squamous cell carcinoma. J Dent Res Feb 20. https://doi.org/10.1177/0022034519828710.

94. Leeming DJ, Willumsen N, Sand JMB, Holm Nielsen S, Dasgupta B, Brodmerkel C, Curran M, Bager CL, Karsdal MA (2018), A serological marker of the N-terminal neoepitope generated during LOXL2 maturation is elevated in patients with cancer or idiopathic pulmonary fibrosis. Biochem Biophys Rep 17, 38-43. https://doi.org/10.1016/ j.bbrep.2018.11.002.

95. Schilter H, Findlay AD, Perryman L, Yow TT, Moses J, Zahoor A, Turner CI, Deodhar M, Foot JS, Zhou W, Greco A, Joshi A, Rayner B, Townsend S, Buson A, Jarolimek W (2019), The lysyl oxidase like $2 / 3$ enzymatic inhibitor, PXS-5153A, reduces crosslinks and ameliorates fibrosis. J Cell Mol Med 23, 3, 1759-1770. https://doi.org/ $10.1111 / \mathrm{jcmm} .14074$.

96. Xu Y, Wang X, Huang Y, Ma Y, Jin X, Wang H, Wang J (2018), Inhibition of lysyl oxidase expression by dextran sulfate affects invasion and migration of gastric cancer cells. Int J Mol Med 42, 5, 2737-2749. https://doi.org/10.3892/ ijmm.2018.3855.

97. Hollande C, Boussier J, Ziai J, Nozawa T, Bondet V, Phung W, Lu B, Duffy D, Paradis V, Mallet V, Eberl G, Sandoval W, Schartner JM, Pol S, Barreira da Silva R, Albert ML (2019), Inhibition of the dipeptidyl peptidase DPP4 (CD26) reveals IL-33-dependent eosinophil-mediated control of tumor growth. Nat Immunol 20, 3, 257-264. https://doi.org/10.1038/s41590-019-0321-5.

98. Zur Hausen H, Bund T, de Villiers EM (2019), Specific nutritional infections early in life as risk factors for human colon and breast cancers several decades later. Int J Cancer 144, 7, 1574-1583. https://doi.org/10.1002/ijc.31882.

99. Tez M (2018), Pragmatic cancer approach - Time to change? 4open 1, 2. https://doi.org/10.1051/fopen/2018002.

100. Brücher BLDM, Li Y, Schnabel P, Daumer M, Wallace TJ, Kube R, Zilberstein B, Steele S, Voskuil JL, Jamall IS (2016), Genomics, microRNA, epigenetics, and proteomics for future diagnosis, treatment and monitoring response in upper GI cancers. Clin Transl Med 5, 1, 1-16. https://doi. org/10.1186/s40169-016-0093-6.

Cite this article as: Brücher B.L.D.M \& Jamall I.S. 2019. Prelude and premise to the special issue: disruption of homeostasisinduced signaling and crosstalk in the carcinogenesis paradigm "Epistemology of the origin of cancer". 4 open, 2 , 6. 